\title{
A Late Caddo Period Vessel from the De Long Farm Site (41AN16) in the Upper Neches River Basin, Anderson County, Texas
}

Timothy K. Perttula

Heritage Research Center, Stephen F. Austin State University

Follow this and additional works at: https://scholarworks.sfasu.edu/ita

Part of the American Material Culture Commons, Archaeological Anthropology Commons, Environmental Studies Commons, Other American Studies Commons, Other Arts and Humanities Commons, Other History of Art, Architecture, and Archaeology Commons, and the United States History Commons

Tell us how this article helped you.

This Article is brought to you for free and open access by the Center for Regional Heritage Research at SFA ScholarWorks. It has been accepted for inclusion in Index of Texas Archaeology: Open Access Gray Literature from the Lone Star State by an authorized editor of SFA ScholarWorks. For more information, please contact cdsscholarworks@sfasu.edu. 


\section{A Late Caddo Period Vessel from the De Long Farm Site (41AN16) in the Upper Neches River Basin, Anderson County, Texas}

\section{Creative Commons License}

\section{(c) (1) \&}

This work is licensed under a Creative Commons Attribution-NonCommercial 4.0 International License 


\title{
A Late Caddo Period Vessel from the De Long Farm Site (41AN16) in the Upper Neches River Basin, Anderson County, Texas
}

\author{
Timothy K. Perttula
}

\section{INTRODUCTION AND SITE SETTING}

The De Long Farm site (41AN16) is in the Caddo Creek valley in the upper Neches River basin in East Texas, about $3.2 \mathrm{~km}$ northwest of the small town of Frankston, Texas (Figure 1). A Caddo midden area was about $200 \mathrm{~m}$ to the east.

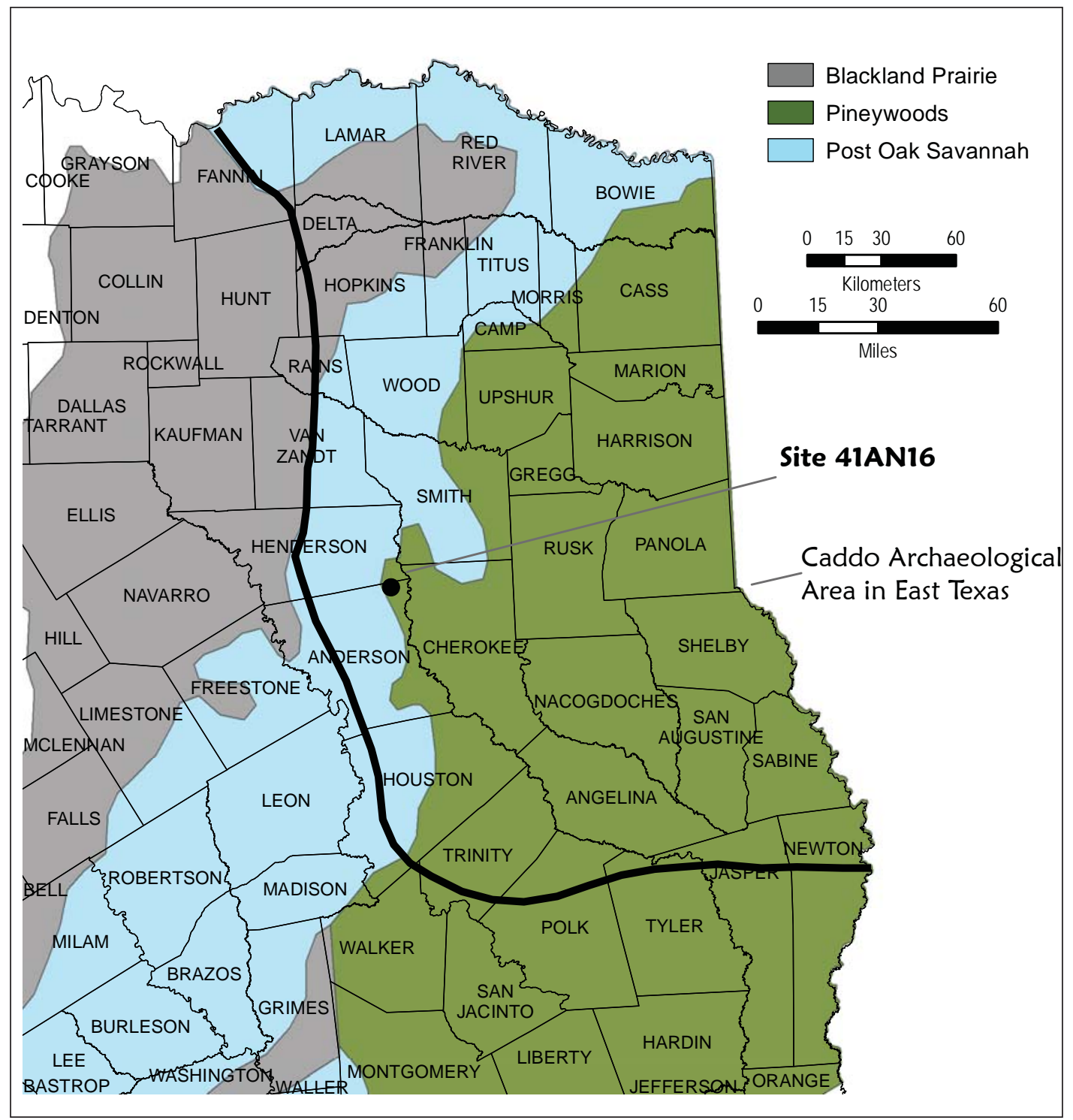

Figure 1. The location of the De Long Farm site (41AN16) in East Texas. 
The site was found by a local farmer after a vessel was discovered in a gully in a field after plowing. University of Texas archaeologists investigated the find spot in October 1935 (Woolsey 1935), but after excavating a large area around the vessel find spot (Figure 2), no other vessels or any evidence of burials were found. UT did purchase the one vessel from the local farmer.

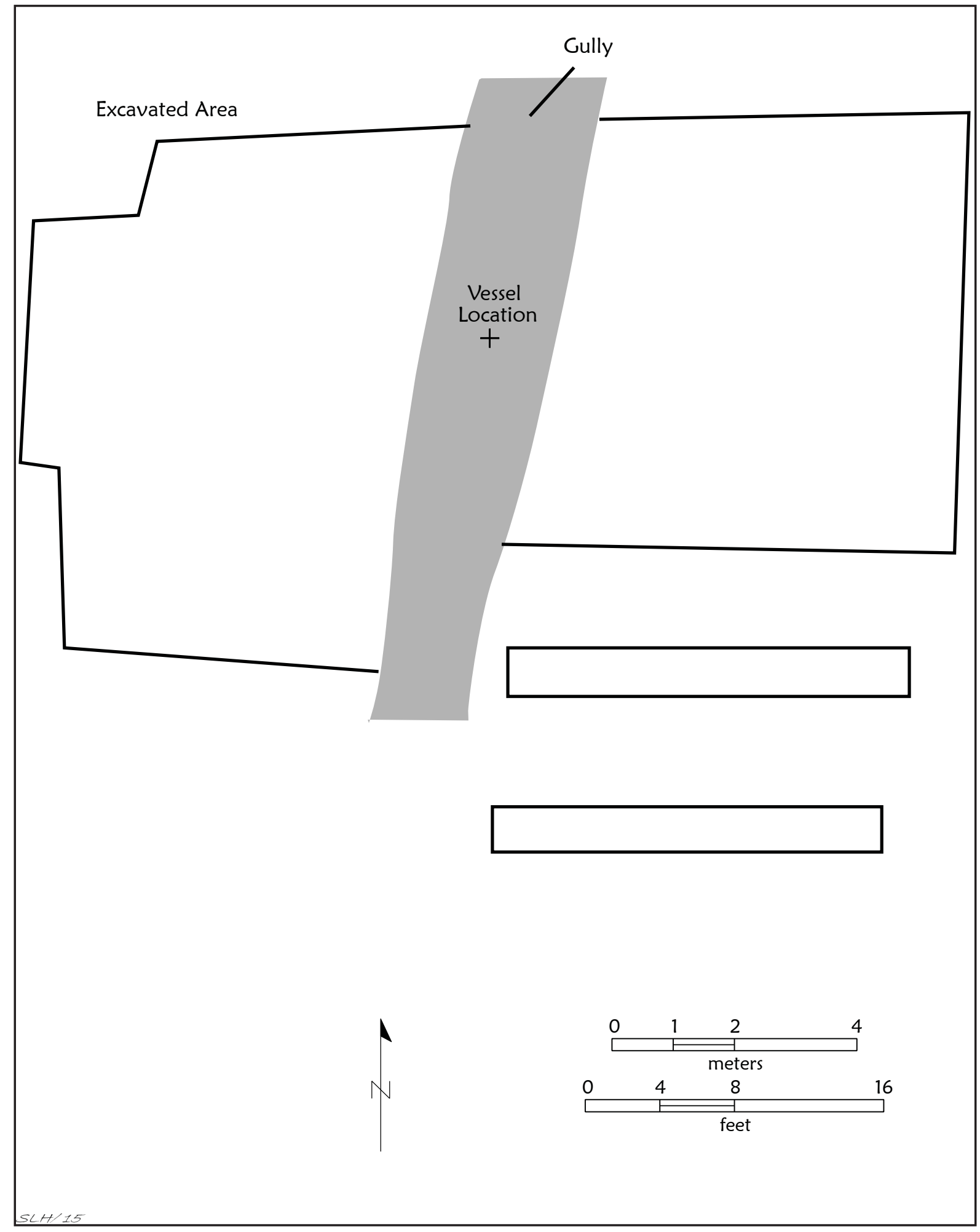

Figure 2. 1935 excavations by UT archaeologists at the De Long Farm site (41AN16). 


\section{Ceramic Vessel from the De Long Farm Site}

SITE NAME OR SITE NUMBER: De Long Farm, also known as Stevenson Estate; 41AN16

VESSEL NO.: 41AN16-1

VESSEL FORM: globular Carinated Bowl

NON-PLASTICS AND PASTE: grog

RIM AND LIP FORM: Direct rim and a rounded lip

CORE COLOR: F (fired in a reducing environment and cooled in the open air)

INTERIOR SURFACE COLOR: dark reddish-brown

EXTERIOR SURFACE COLOR: dark reddish-brown

WALL THICKNESS (IN MM): rim, $5.1 \mathrm{~mm}$

INTERIOR SURFACE TREATMENT: smoothed

EXTERIOR SURFACE TREATMENT: burnished

HEIGHT (IN CM): 7.3

ORIFICE DIAMETER (IN CM): 9.8

DIAMETER AT BOTTOM OF RIM OR NECK (IN CM): 9.8

BASE DIAMETER (IN CM) AND SHAPE OF BASE: 6.4; circular and flat

ESTIMATED VOLUME (IN LITERS): 0.43

DECORATION (INCLUDING MOTIF AND ELEMENTS WHEN APPARENT): The rim panel (as defined by upper and lower horizontal engraved lines, one under the lip and the other just above the vessel carination) is divided into eight sections by a repeating series of excised brackets (Figure 3).

PIGMENT USE AND LOCATION ON VESSEL: none

TYPE AND VARIETY (IF KNOWN): Poynor Engraved, var. Hood (see Perttula 2011:Figure 6-64e).

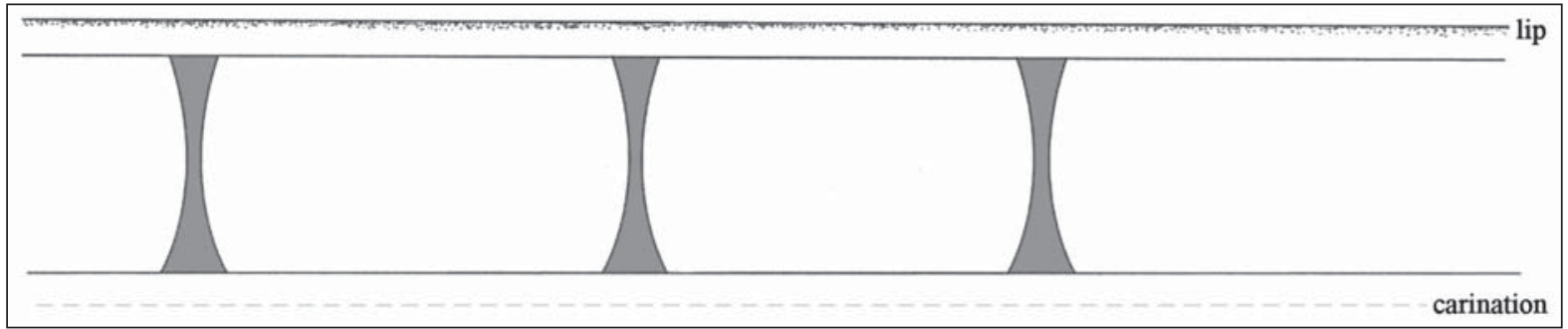

Figure 3. Poynor Engraved, var. Hood carinated bowl from the De Long Farm site (41AN16). 


\section{SUMMARY}

An ancestral Caddo ceramic vessel was discovered by a farmer on the De Long Farm in 1935, and UT archaeologists excavated a large area around the vessel find spot in October 1935, but found no other vessels or evidence of any burials. Given that the vessel was found in an eroded gully, it is likely that a single Caddo burial had been eroded away some time previously, and the one vessel remaining was one (if not the only) funerary offering associated with this burial.

The ceramic vessel found at the De Long Farm site is a globular Poynor Engraved, var. Hood carinated bowl. This style of engraved vessel is common in ca. A.D. 1480-1650 Frankston phase contexts in the upper Neches River basin in East Texas (Perttula 2011:Table 6-37).

\section{ACKNOWLEDGMENTS}

As always, I appreciate the assistance of Jonathan Jarvis at the Texas Archeological Research Laboratory, The University of Texas at Austin for providing access to the records and collections from the W. T. Robinson Farm site. Lance Trask prepared the figures in this article.

\section{REFERENCES CITED}

Perttula, T. K.

2011 The Ceramic Artifacts from the Lang Pasture Site (41AN38) and the Place of the Site within an Upper Neches River Basin Caddo Ceramic Tradition. In Archeological Investigations at the Lang Pasture Site (41AN38) in the Upper Neches River Basin of East Texas, assembled and edited by T. K. Perttula, D. B. Kelley, and R. A. Ricklis, pp. 145-320. Archeological Studies Program Report No. 129, Texas Department of Transportation, Environmental Affairs Division,

Woolsey, A. M.

1935 Notes on Field Work De Long Farm 2 Miles Northwest Frankston Anderson County October 17, 1935. MS on file, Texas Archeological Research Laboratory, The University of Texas at Austin. 